\title{
Enhancing ‘ICT Teaching’ in English Schools: Vital Lessons
}

\author{
Peter Twining ${ }^{1} \&$ Fiona Henry, ${ }^{1, *}$ \\ ${ }^{1}$ Faculty of Education and Language Studies, The Open university (UK), Walton Hall, Milton Keynes, MK7 6AA, UK \\ *Corresponding author: Faculty of Education \& Language Studies, The Open University, Level 2, Stuart Hall \\ Building, Walton Hall, Milton Keynes, MK7 6AA, UK. Tel: 44-1908-652-602. E-mail: fiona.henry@open.ac.uk
}

Received: January 29, 2014 Accepted: February 25, 2014 Online Published: March 4, 2014

doi:10.5430/wje.v4n2p12ＵRL: http://dx.doi.org/10.5430/wje.v4n2p12

\begin{abstract}
Despite substantial investments in digital technology in schools the impact has been less than advocates anticipated. This raises issues about the effectiveness of past approaches to the continuing professional development (CPD) of teachers. Vital was a £9.4million programme, funded by English governments between 2009 and 2013, to enhance the use of digital technology and the teaching of computing in schools. Vital, which was provided by the Open University (UK), developed an evolving range of professional development, informed by a review of the literature and extensive experience of supported open learning and developing online communities. Underpinning all of Vital's provision was a view of teachers as experts, and practitioner research as incorporating all the key elements of effective CPD identified in the literature. The evolving models of CPD developed by Vital during three distinct phases of its operation are described. These include: supported online courses; community websites; TeachMeets and TeachShares; the In-house Professional Development Partnership; and the development and sharing of evidence through EdFutures.net. Based on Vital's experiences some suggestions are made about what constitutes effective CPD.
\end{abstract}

Keywords: continuous professional development (CPD); ICT; Vital

\section{Introduction}

This article provides an account and analysis of the effectiveness of the models of continuing professional development (CPD) provided by Vital, a successful £9.4million programme to enhance the quality of 'ICT teaching' in state funded 5-19 education in England between July 2009 and March 2013.

The paper provides a review of the literature that informed the design of Vital's provision and describes how that provision evolved through three stages, informed by on-going applied research. Part of Vital's significance is that it explicitly set out to harness the potential of online learning and Web 2.0 to enhance ICT CPD, which Daly et al. (2009a) had highlighted. In so doing Vital aimed to address the lack of evidence that Daly et al. had identified about how this might work in practice to bring about change in classrooms.

The term 'ICT teaching' was used at the time Vital was commissioned to include the use of digital technology to support learning across the curriculum, and the teaching of the specialist subjects called ICT, Information Technology (IT) and Computer Science. This highlights a historical problem, namely, that terminology in this field has been confused and confusing (Twining, 2002a). Thus, the term ICT has been used to refer to all aspects of the use of digital technology within schools, encompassing the specialist subjects (including Digital Literacy, IT, and Computer Science), plus the use of digital technology to support learning across the curriculum, as well as the digital technology itself. This ambiguity was exacerbated, at least within the English context, during the final phases of Vital due to proposals that the name of the National Curriculum subject be changed from ICT to Computing (DfE, 2013). In order to assist with clarity in this article Twining's (2013b) definitions of terminology are used, see Table 1. It should be noted that these were NOT the definitions in use before April 2013 and are still contested. 
Table 1. Definitions of Terms (based on Twining, 2013b)

Computing: The National Curriculum subject, which should encompass:

Computer Science: the scientific discipline of Computer Science, covering principles such as algorithms, data structures, computational thinking, programming, systems architecture, design, problem solving etc.

Information Technology (IT): the assembly, deployment, and configuration of digital systems to meet user needs for particular purposes. (Note that this is narrower than the use in industry, which generally encompasses Computer Science as well)

Digital literacy: the ability to operate effectively as a citizen in the 21st century. It covers the following areas:

- Understanding the impact of new technologies on society, including the ways in which new technologies change disciplines (e.g. history, chemistry, English, etc.)

- Understanding the nature of digital identities and being able to manage your digital identities appropriately

- Being able to interact safely in a digital world (encompassing e-safety, cyber-bullying, data security, etc.)

- Being able to locate, organize, understand, evaluate, analyse and (re)present information using digital technology (including using dynamic and procedural representations) - what you might think of as 'the creative' making and doing aspects of using digital technology (though of course many other aspects of the subject are creative too).

ICT: the cross curricula use of digital technology, which can be subdivided into:

Embedded Technology (ET): the use of digital technology where it has changed the nature of a subject (other than Computing) and is thus now an integral part of that subject. For example, in PE where it allows you to analyse performance, or history where it allows you to analyse vast data sets (and in so doing extends the sorts of questions you can ask), or in the natural sciences where it allows you to measure and record much more accurately (again changing the sorts of questions you can ask and answer).

Technology Enhanced Learning (TEL): the use of digital technology to extend (and enhance) our repertoire of teaching strategies/methods (i.e. Pedagogy)

Digital technology: the equipment (hardware and software) and infrastructure that is needed in order to engage with Computing and ICT.

This account of Vital is partial, in two senses; it focuses on specific aspects of Vital and is thus incomplete, and it is only one of many possible accounts, based on the perspectives of the authors, both of whom were staff working on Vital, and thus is subjective. If one adopts a sociocultural perspective, as members of Vital did, then partiality is inevitable.

From a sociocultural perspective, in which knowledge is co-constructed and situated, one needs to understand the changing contexts within which Vital was operating in order to be able to make sense of the programme. This aligns with the view that in order to be successful professional development should take note of knowledge of the context of teachers' practice, policy imperatives, emerging pedagogical practice and current research (Cochran-Smith \& Lytle, 1999; Scheerens, 2010). Thus the article starts with a brief overview of the broader context within which Vital was initially established, and then looks at three distinct phases of the programme, before drawing some conclusions about what constitutes effective CPD in practice.

\section{Before Vital (1980 to 2008)}

Digital technology has been in use in schools in England since at least 1980 when the Microelectronics Education Programme (MEP) started. Since then substantial investment has been made in digital technology in schools:

- Twining (2002a) estimated that between 1985 and 1992 over £200million was spent on digital technology in English state schools;

- Barton (2009) estimated that between 1998 and 2008 primary and secondary schools in the UK spent 
around £1.36billion on digital technology (including professional development);

- BESA (2009) estimated that UK schools had budgets for digital technology, excluding software, of £576.8million in 2009/10.

Less substantial, but still significant amounts of money have been spent on professional development for teachers. Thus, for example, between 1999 and 2003 the UK government spent £230million from the New Opportunities Fund (NOF), on a scheme to improve ICT in schools, and between 2005 and 2010 the £55billion Building Schools for the Future programme included a significant level of funding for ICT professional development. This raises a question about the reasons underpinning this level of investment, and the impact that it has had.

A review of the literature (Twining, 2003) identified 19 discrete rationales for using digital technology in education (see Table 3). Given that each rationale relates to different intended impacts, analysing how digital technology was being used in schools and the impacts it was having was extremely complex. The Computer Practice Framework (CPF) was developed to help address this problem, by providing a tool to support analysis of the ways in which digital technology could be used in education and the impacts that such use might have (Twining, 2002a, 2002b, 2008).

The CPF consisted of three dimensions, which between them encapsulate the critical elements of use of digital technology in education. Figure 1 illustrates these three dimensions and how they are inter-related.

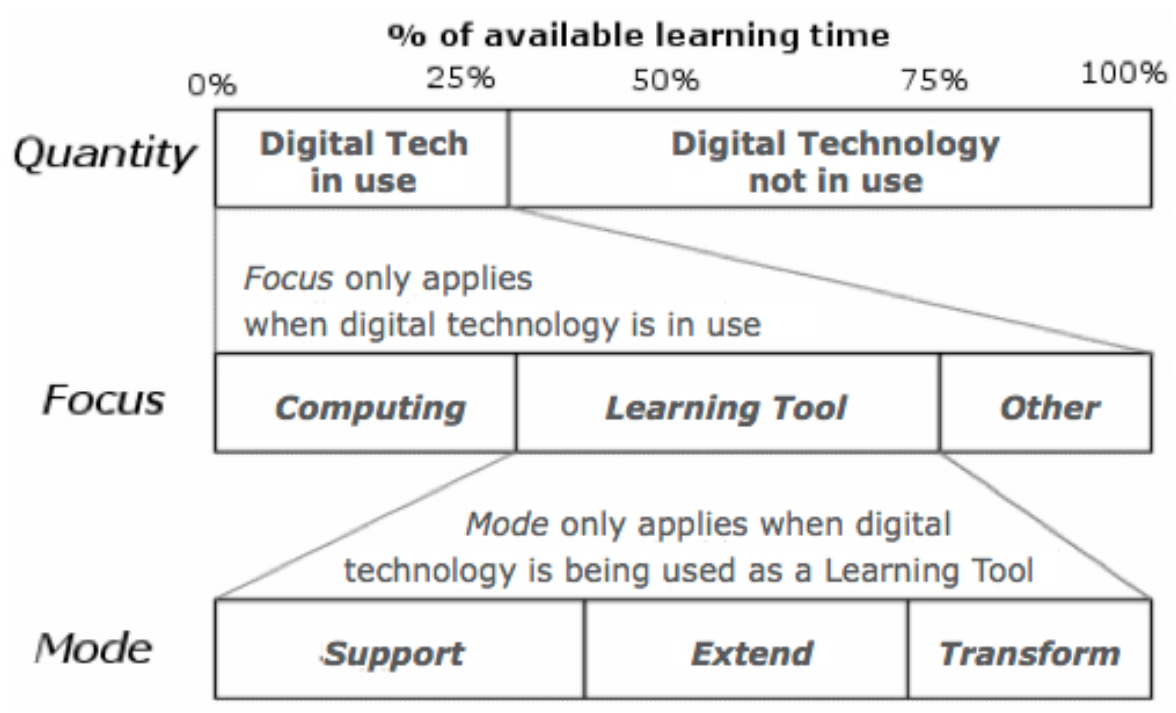

Figure 1. The Three Dimensions of the CPF and How They Inter-Relate (adapted from Twining, 2008, p. 565)

Quantity relates to the proportion of available learning time that digital technology is being used by the learner. This underpins the other two dimensions. The Focus, which is defined in Table 2, then categorises the objectives underlying the use of digital technology. As illustrated in Figure 1, if digital technology is not in use then the Focus dimension does not apply.

Table 2. The Focus Dimension of the CPF (based on Twining, 2008, p. 566)

\begin{tabular}{ll}
\hline Category & Definition \\
\hline Computing & $\begin{array}{l}\text { Using digital technology in a way that helps children to develop their Computing skills, } \\
\text { knowledge and understanding }\end{array}$ \\
\hline Learning Tool & $\begin{array}{l}\text { Using digital technology in a way that supports any aspect of children's learning other than } \\
\text { Computing itself (equivalent to ICT) }\end{array}$ \\
\hline Other & Using digital technology in a way that is not covered by Computing or Learning Tool. \\
\hline
\end{tabular}

Mapping the 19 distinct rationales for using digital technology in education on to the Focus Dimension (see Tables 3a to 3c) helps to simplify their analysis 
Table 3a. Rationales That Fit into the IT Category

1. In order to learn IT Integration - learning IT skills (through the medium of other subjects) (Anderson and skills

Collis, 1993 in Harris, 1999).

As part of the curriculum (Scott et al., 1992 in Harris, 1999).

The Computer Practice Framework (CPF): Focus = IT (Twining, 2001a, 2002a, 2002b)

Table 3b. Rationales That Fit into the Learning Tool Category

2. As a tool to Infusion - use computers to support learning in other curriculum areas (Anderson and Collis achieve traditional 1993 in Harris , 1999).

teaching and learning goals across the curriculum

As a tool to achieve traditional pedagogical goals (Scott et al., 1992 in Harris, 1999).

Integration of drill and skill and/or other software with other activities (Clements et al., 1993; Harris, 1999)).

Pedagogical rationale - "computers may improve the instructional processes and learning outcomes." (Pelgrum \& Plomp, 1991, p. 3).

The Computer Practice Framework (CPF): Focus = Learning Tool (Curriculum Tool), Mode = Support (Twining, 2001a, 2002a, 2002b).

3. In order to extend 'Neoprogressives' [social constructivists] want learning communities - and see computers as and enrich learning 'mind-tools' that can make this possible (Cuban, 1993).

across the curriculum

Use of problem-solving software and tools (e.g. word processors, Logo, drawing packages) to extend and enrich learning (Clements et al., 1993; Harris, 1999).

As a major framework for learning in certain disciplines, notably languages (Hexel, De Marcellus, \& Bernoulli, 1998).

The Computer Practice Framework (CPF): Focus = Learning Tool (Curriculum Tool), Mode = Extend (Twining, 2001a, 2002a, 2002b).

4. In order to motivate learners

To unlock new attitudes and behaviours, hopefully to be transferred to other learning situations (Hexel et al., 1998).

The Computer Practice Framework (CPF): Focus = Learning Tool (Affective Tool) (Twining, 2001a, 2002a, 2002b).

5. As a catalyst for educational change

Redefining teachers' roles with a move towards resource management and more independent learning by pupils (Moseley et al., 1999).

Catalytic rationale - "the use of computers may accelerate another educational innovation .... the possibility that schools can be changed for the better by the introduction of new technologies" (Pelgrum \& Plomp, 1991, p. 3).

The Computer Practice Framework $(\mathrm{CPF})$ : Focus = Learning Tool, Mode = Extend $($ Twining, 2001a, 2002a, 2002b).

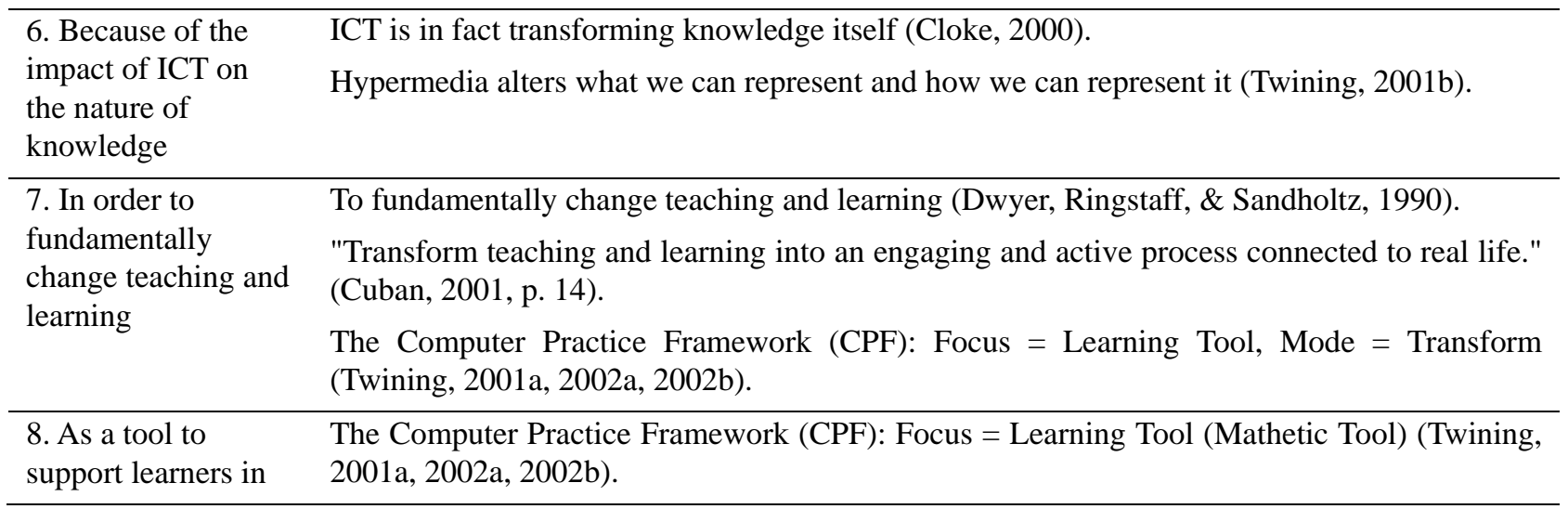


thinking about their

own learning

$\begin{array}{ll}\begin{array}{l}\text { 9. In order to } \\ \text { provide access to }\end{array} & \text { The Computer Practice Framework (CPF): Focus = Learning Tool (Curriculum Tool) } \\ \text { the curriculum for } & \\ \text { those who might } \\ \text { otherwise be } \\ \text { excluded from it }\end{array}$

Table 3c. Rationales That Fit into the Other Category

10. In order to increase Need for greater productivity in education (Cuban, 1993). productivity in education

11. In order to reduce the cost of Cost-effectiveness rationale - reduce the cost of education (Pelgrum \& Plomp, education 1991).

12. In order to make education Help teachers to do their jobs as they do them now (Moseley et al., 1999). more efficient

"Make schools more efficient and productive than they currently are." (Cuban, 2001, p. 13).

The Computer Practice Framework (CPF): Focus = Other (Twining, 2002a, 2002b).

13. As a substitute for teachers As a substitute for the teacher (Scott et al., 1992; Harris, 1999).

14. In order to reward learners $\quad$ As a reward [for children] (Clements et al.;1993; Harris, 1999).

The Computer Practice Framework (CPF): Focus = Other (Twining, 2002a, 2002b).

15. As preparation for living in a society that is permeated with technology

Social rationale - preparation for living in a society that is permeated with technology (Pelgrum \& Plomp, 1991).

Need to prepare students for the future (and computers are the future) (Cuban, 1993).

\section{As preparation for work Vocational rationale - preparation for work (Pelgrum \& Plomp, 1991). (employment) \\ "Prepare the current generation of young people for the future workplace." (Cuban, 2001, p. 15).}

17. In order to support and stimulate the country's economic development

$\begin{aligned} & \text { 18. In order to impress } \\ & \text { stakeholders (e.g. inspectors, }\end{aligned}$ Plomportunistic rationale - attract more students to the school (Pelgrum \&
$\begin{aligned} & \text { funders, } \\ & \text { parents/students) }\end{aligned}$

19. In order to reduce inequalities The Computer Practice Framework (CPF): Focus = Other (Twining, 2002a, between students/pupils with 2002b).

differential access to ICT outside

formal education

The Mode Dimension of the CPF builds upon the Focus dimension, as illustrated in Figure 1, to show the impact that digital technology might have when it is being used as a Learning Tool. The Mode specifically looks at the impact of using digital technology as a Learning Tool in relation to changes in the curriculum and pedagogy, as illustrated in Figure 2. It thus reflects that digital technology can:

- change the nature of disciplines, providing new epistemological and methodological tools. For example, digital technology provides historians with new ways of collecting and analysing data, and new methods for 
representing and communicating their understanding, which change the sorts of questions that historians can ask and the approaches they can take to answering them - in effect providing different lenses through which historians can look;

- provide additional ways of supporting learning. For example, students can use simulations to carry out experiments that would be too dangerous or impractical without digital technology, they can use digital technology to record and review their performance, and they can access vast quantities of information and access experts across the globe.

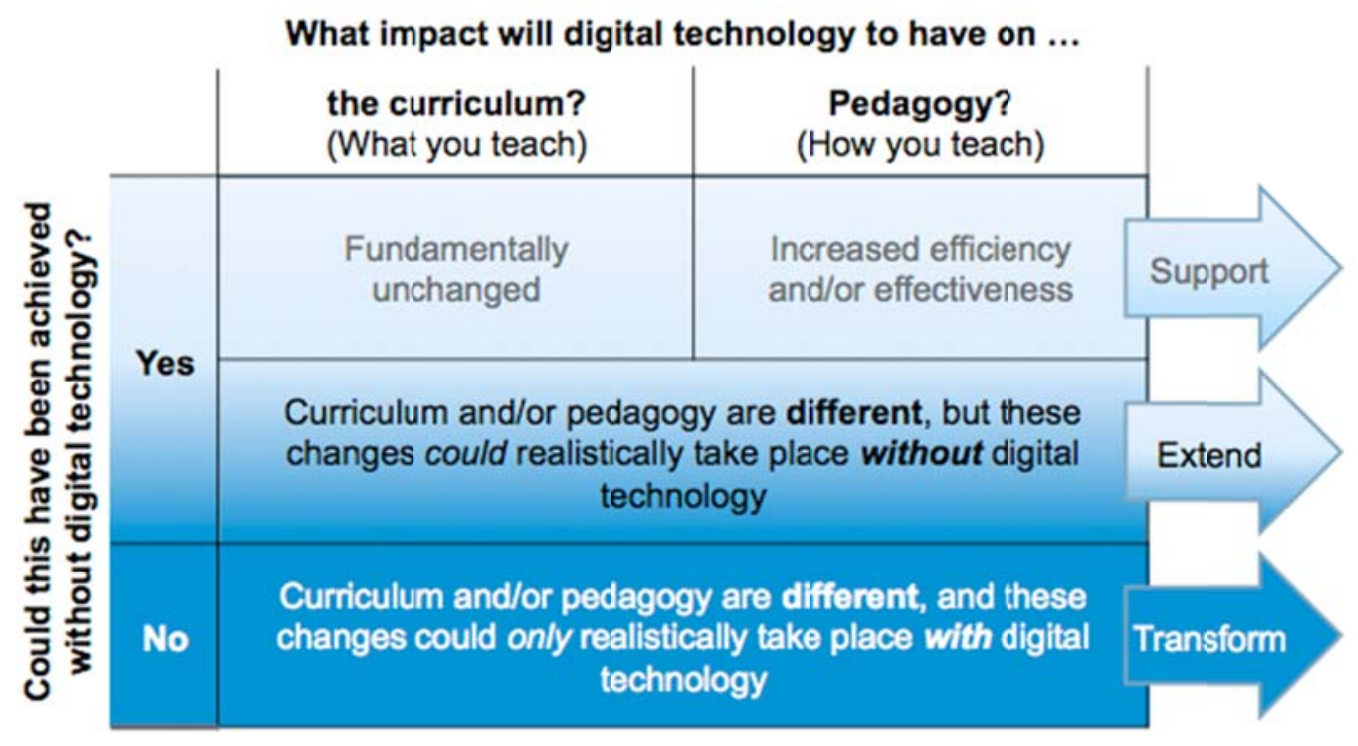

Figure 2. Explanation of the Categories on the Mode Dimension of the CPF

Advocates of the investment in digital technology tended to claim that it would transform education (e.g. Culp, Honey, \& Mandinach, 2005; DfES, 2002a, 2002b, 2003, 2005). Kozma (2003a, 2003b) in their analysis of 174 case studies of the impact of ICT on practice suggested that pedagogical transformation involved changes in the nature of the roles of teachers and students. The Schome Park Programme (http://www.schome.ac.uk/wiki/The_Schome_Park_Programme), which used Teen Second Life ${ }^{\mathrm{TM}}$ with a wiki, forum and blog to extend thinking about what education systems could be like, identified nine dimensions of practice that need to be considered when thinking about educational transformation, which they labelled: roles, relationships, curriculum, discipline, theoretical stance, motivation, focus, perspective and stance (Twining, 2010). However, there is little evidence that digital technology has transformed education (Luckin et al., 2012). Despite the huge level of investment in digital technology and professional development the impact on schools has been less significant than anticipated. This 'rhetoric reality gap' (Trend, Davis, \& Loveless, 1999) was recognised by the Labour Government's Department of Children, Schools and Families (DCSF), who put out a call in early 2009 for tenders to provide a national programme of CPD to enhance ICT and the teaching of computing in state funded 5-19 education in England. This aimed to complement and enhance the ICT and computing CPD provision already available at the time, which was patchy (Hollingworth, Allen, Hutchings, Kuyok, \& Williams, 2008) and varied in quality and type (Daly et al., 2009a).

\section{Vital's Proposed CPD Model (Early 2009)}

Teachers and more specifically, teacher competency is central to promoting quality learning in classrooms (e.g. Bell \& Gilbert, 1996; Coolahan, 2005; Elmore, 2000; Fullan, 1990) because the quality of instruction is one of the key determinants of pupils' achievement (Rivkin, Hanushek, \& Kain, 2005). Professional development is widely recognised as being an essential part of school improvement in general (e.g. Bolam, 2000; Hargreaves, 1994). Preparing teachers to integrate ICT into their pedagogical practice is made more challenging by the instability associated with the rapid development of technology (Borko, Whitcomb, \& Liston, 2008) and effective CPD is essential if digital technology is going to be integrated successfully and in a sustained way in primary and secondary education (Davis, Preston, \& Sahin, 2009; Haydn \& Barton, 2007; Somekh, 2008). Indeed Culp, Honey and 
Mandinach (2005, p. 292) identify high quality CPD as "the single most important step towards the infusion of technology in education". It has been argued that $30 \%$ of any funding on digital technology in schools should be devoted to professional development in order to ensure that it is used effectively (Twining, Raffaghelli, Albion, \& Knezek, 2013). This begs the question 'what does effective CPD look like?'

In early 2009, when Vital was being planned, the predominant model of CPD in English schools took the form of face-to-face training. This typically either involved short courses after school or one-off whole day events. In both cases training often took place off the school site, and in the case of ICT and computing, CPD frequently involved the use of digital technology that was not available in the participants' schools. Such CPD was widely recognised as being ineffective because it tended to be short term, unrelated to the teachers' current classroom needs, and teachers didn't have the opportunity to try out and reflect on what they were learning in their own classrooms (e.g. Daly, Pachler \& Pelletier, 2009b). However, this appeared to be the model envisaged by the DCSF in the original tender, which stipulated that the winner of the contract should provide face-to-face CPD in regional centres in the nine government regions within England.

A review of recent and relevant literature at the time identified effective CPD as being:

- strategic and impact focused (involving the senior management team, linking with the school development plan, and being integrated with the school's self-review \& performance management processes) (Coolahan, 2002; McCormick et al., 2008; Murchan, Loxley \& Johnston, 2009; Ofsted, 2006; Pedder, Storey \& Opfer, 2008);

- context relevant (in relation to pupils, teachers, classrooms and the school as a whole) (Daly et al., 2009a; Fraser, Kennedy, Reid \& Mckinney, 2007; McCormick et al., 2008; Murchan et al., 2009; OECD, 1998; Ofsted, 2006; Pedder et al., 2008);

- informed by external expertise (alongside internal staff expertise) (Coolahan, 2002; Cordingley, Bell, Isham, Evans \& Firth, 2007; Daly et al., 2009a, 2009b; McCormick et al., 2008; OECD, 1998);

- collaborative, experimental \& reflective (Coolahan, 2002; Daly et al., 2009a; Fraser et al., 2007; McCormick et al., 2008; Murchan et al., 2009; OECD, 1998; Ofsted, 2006; Pedder et al., 2008);

- $\quad$ evidence/research informed (Baumfield, Hall \& Wall, 2008; Hall, 2009; McCormick et al., 2008; Pedder et al., 2008);

- $\quad$ sustained (McCormick et al., 2008; Opfer, Pedder \& Lavicza, 2008);

- evaluated (in relation to planned impact) (McCormick et al., 2008; Ofsted, 2006; Opfer et al., 2008).

Daly et al. (2009a) who reviewed the literature on effective ICT CPD also highlighted the overemphasis on skills training, at the expense of pedagogy, and the importance of having easy access to the digital technology that the CPD related to.

This overall analysis did not seem to fit well with the predominant models of CPD at the time or with the DCSF's expectations for the programme. Indeed, Opfer et al. (2008, p. 115) stated that "The overall pattern of CPD [in England], however, is of not very effective activity." The academic leading the Vital bid thus set out to devise a model of provision that aligned with his sociocultural perspective and with the features of effective CPD identified in the literature. His prior work on action research (Selwood \& Twining, 2005) suggested a close mapping between the features of effective CPD and Action Research. This led to the development of the Vital Practitioner Research Cycle, which builds upon the concept of reflective practice (Stenhouse, 1979) as illustrated in Figures 3 and 4. 


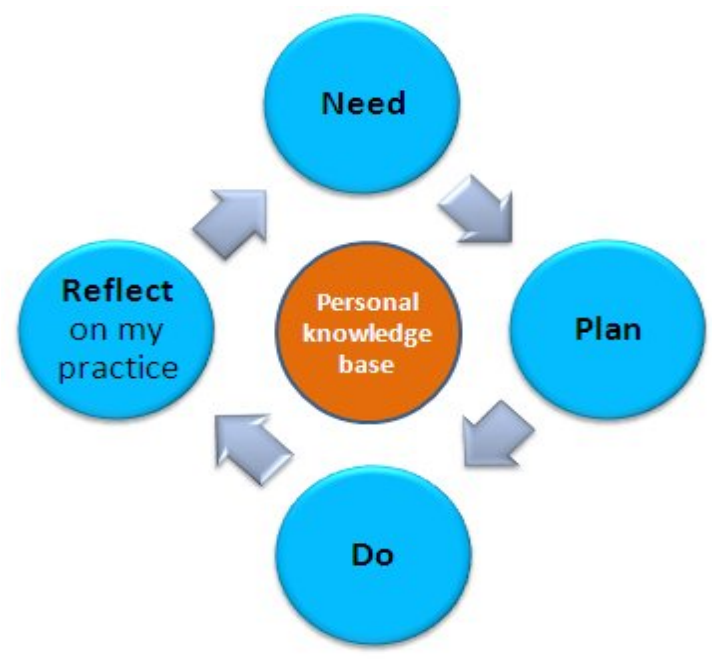

Figure 3. A Typical Reflective Practitioner Cycle

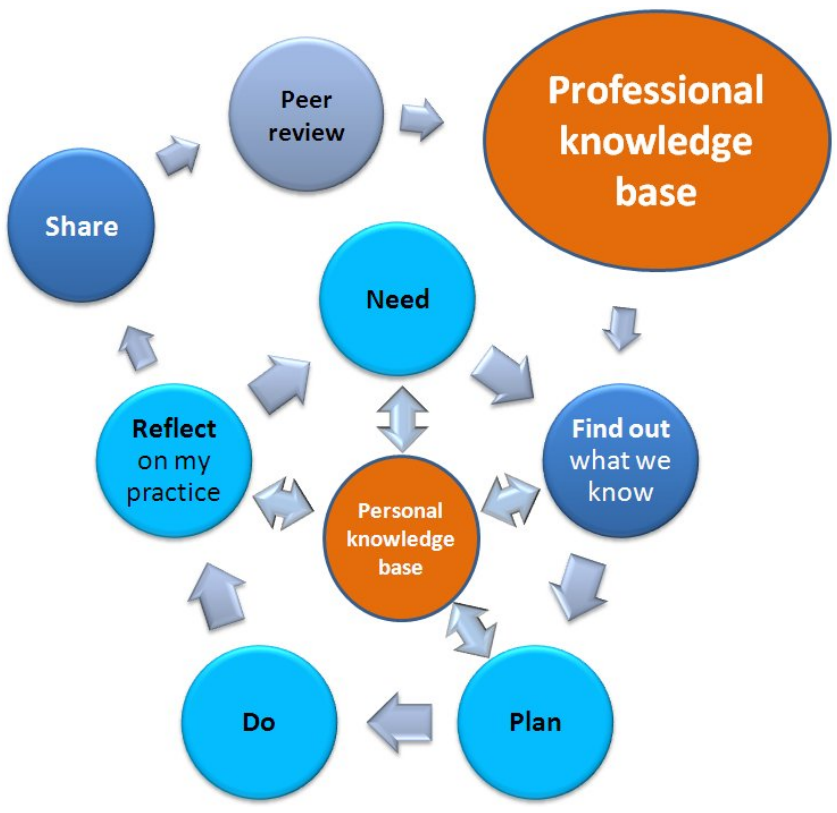

Figure 4. The Vital Professional Research Cycle

The Vital Practitioner Research Cycle aimed to help address the relative isolation of teachers, which has been identified in the literature (e.g. Heider, 2005; Lortie, 2002), by adding in the expectation that having identified a need the next step is to find out what the wider education community (Professional knowledge base) already knows about how to address that need. Similarly, by adding in a step in which teachers share their learning with the wider community the Vital Practitioner Research Cycle aimed to help to increase the extent to which teachers were seen as being 'the experts' in education, thus helping to reverse the deprofessionalisation of teaching in which teachers' expertise often isn't recognised or valued (OECD, 2009).

The challenge was how to reify the Vital Practitioner Research Cycle in Vital's proposed provision. Building on the expertise of team members, which included designing online courses within the UK's Open University (OU) and developing successful online communities both within OU teaching (e.g. Goodliff \& Twining, 2008) and as part of research on future education systems (e.g. Twining \& Footring, 2010) a model was devised that incorporated two linked core elements:

- a national website to support collaboration and sharing between practitioners;

- $\quad$ supported distance learning courses, built explicitly around the Vital Practitioner Research Cycle. 


\subsection{The Website}

The website aimed to address the lack of infrastructure to support collaboration between schools that the Organisation for Economic Co-operation and Development (OECD, 2009) had identified existed in many countries. Whilst it is widely recognised that developing genuine collaboration amongst teachers is very challenging (Hargreaves, 2010), online communities have been proposed as offering potential solutions. For example, Looi, Lim and Chen (2008), building on Lave and Wenger's (1991) seminal work on Communities of Practice (CoPs), argued that digital technology offered new opportunities for professional growth and identity formation for teachers through online CoPs.

Given Vital's aim was to extend and transform practice (as defined in the CPF), which fits with the 'transitional' and 'transformative' categories within Kennedy's (2005) framework for analysing professional learning, the focus was to develop a website that enabled community members to have greater ownership and control.

Following Fraser et al.'s (2007, p. 165) claim that "Inclusion of formal and informal planned opportunities is more likely to result in transformational learning" the website was envisaged as a vehicle to support sharing of teachers' expertise through a national online community that incorporated both formal and informal elements. These included Vital's courses, a series of short structured CPD events such as keynote video presentations, and the ability for members to set up their own collaborative spaces.

\subsection{Vital's Course Model}

McCormick, Banks, Morgan, Opfer, Pedder, Storey and Wolfenden (2008) reported that there was little evidence of online CPD in the UK, with some evidence that teachers view online courses as of poor quality. However, this contrasted with the experience of students on Open University courses, which are seen as being of high quality (e.g. Horne, 2010). The Open University's model of supported distance learning also offered economies of scale, allowing Vital's bid for the DCSF contract to set high targets for levels of teacher engagement whilst making it possible for teachers to participate from within their own school or home.

Vital's course materials were structured around the Vital Practitioner Research Cycle and thus started from an identified need, provided information about how that need had been met in schools, and then asked participants to plan, implement and evaluate how they would address that need in their own context. Each course ended with participants sharing their reflections within the course cohort (via text-based asynchronous forums) and having the opportunity to share a synthesis of their group's learning from the course more extensively via the Vital website.

ICT involves what Mishra and Koehler (2006) called TPCK; a mix of subject knowledge, pedagogical expertise and technical competence. This theoretical framework builds upon Shulman's (1986) notion of pedagogical content knowledge (PCK), in which subject knowledge and pedagogical knowledge are seen as being intimately linked. Mishra and Koehler argue that in the same way that "subject matter is transformed for teaching" (p. 1021), both subject matter and how we teach it are mediated and thus changed by digital technology. Considering the interactions of all three elements of TPCK is essential for effective use of digital technology in schools. In contrast to most previous ICT CPD, the Vital courses planned to focus on the pedagogic use of digital technologies in a subject context, providing opportunities to try out those uses in school, backed up by links to information about how to operate the technology should that be needed.

\subsection{Outcomes}

In June 2009 Vital was awarded the original DCSF contract worth £5.65million to support staff in state funded 5-19 education in England to enhance the quality of ICT and the teaching of computing. One of the strengths of the bid was that Vital's proposed provision was itself a model of transformative learning, something which Condie and Livingstone (2007) identified as being necessary in order to transform learning in schools. Another was that independent evaluation of Vital's impact, which used Guskey's (2000) five levels (see Table 4), was an integral part of the model. Vital's fifth Key Performance Indicator (KPI) related specifically to performance, at Guskey Level 4. 
Table 4. Summary of Guskey’s (2000) Five Levels for Evaluating Professional Development

\begin{tabular}{|c|c|c|}
\hline & Level & Explanation \\
\hline 1 & Participants’ Reactions & $\begin{array}{l}\text { The extent to which participants enjoyed the experience and } \\
\text { thought that it was useful. }\end{array}$ \\
\hline 2 & Participants' Learning & $\begin{array}{l}\text { The extent to which the participants acquired new knowledge } \\
\text { or skills (achieved the intended learning outcomes) }\end{array}$ \\
\hline 3 & Organisational Support and Change & $\begin{array}{l}\text { The extent to which the organisation supported and/or was } \\
\text { changed by the provision. }\end{array}$ \\
\hline 4 & $\begin{array}{l}\text { Participants' Use of New Knowledge and } \\
\text { Skills }\end{array}$ & $\begin{array}{l}\text { The extent to which participants effectively applied their } \\
\text { learning (see Level 2). }\end{array}$ \\
\hline 5 & Student Learning Outcomes & $\begin{array}{l}\text { The extent to which the provision impacted on pupils in terms } \\
\text { of behaviours, motivation, attitudes, dispositions or learning } \\
\text { outcomes. }\end{array}$ \\
\hline
\end{tabular}

\section{Phase 1: Collaboration (July 2009 - Mar 2011)}

Phase 1 was divided into two sub-phases. Phase 1a, which ran from July to December 2009 was a start-up phase, during which staff were appointed in each of the nine government regions in England, the website was developed (based on the OU's existing OpenLearn Moodle site), and the first tranche of course materials were developed. Phase 1b, which ran from January 2010 to March 2011 was the transaction phase, during which Vital rolled outs its provision. In keeping with the underlying practitioner research model, Vital continued to evaluate and evolve its provision based on evidence of its effectiveness. This resulted in the re-design of the courses, adoption of TeachMeets, development of TeachShares and a shift towards the use of Personal Learning Networks (PLNs). Each of these developments is described below.

\subsection{Vital's Courses}

At the start of Phase 1 Local Authorities (LAs) played a key role in state funded (public) education in England, including providing extensive CPD to schools. Vital took the view that its role should be to help teachers identify the best available existing CPD and fill any gaps in provision through its own courses. In order to maximise its impact Vital set out to collaborate with other providers, helping to promote their courses, and buying in their staff to act as tutors on Vital's courses. Vital liaised with LAs and other providers of CPD such as City Learning Centres, who acted as mediators between schools and Vital's course provision.

By May 2010 it was clear that Vital's courses were not recruiting well. In order to make them more attractive to teachers and more cost effective to develop, the second tranche of courses, for release in September 2010, were designed as projects that teachers would carry out in their classrooms over half a term. However, these too recruited poorly, and data Vital had collected confirmed that teachers were resistant to online courses which they anticipated would be geeky, isolating, of poor quality, and possibly most importantly, undertaken in their own time rather than as part of their normal school day. Perhaps equally seriously, in trying to model transformative practice (Bradshaw, Twining, \& Walsh, 2011; Walsh, Bradshaw, \& Twining, 2011) Vital's courses challenged teachers' beliefs, which are critical factors in the adoption of ICT (Ertmer, 2005). Vital had been working on the premise that changes in teacher beliefs follow, rather than precede and cause changes in behaviour (Guskey, 2002). However, as Belland (2009) has argued, the habitus of extended exposure to traditional educational approaches, such as 12 years of primary and secondary schooling in which digital technology is not an integral part, makes it difficult for teachers to change their practice.

As a result of the failure to recruit teachers on to its courses, alternative forms of informal CPD, such as TeachMeets, TeachShares, and Personal Learning Networks (PLNs), which Vital had been experimenting with, became much more significant parts of its provision during the second half of Phase 1b. Support for such approaches came from Lieberman \& Pointer Mace (2010) who argued, based on their experience of working with teacher communities, that making practice public through the use of social networking and new media approaches can transform teachers' practice.

\subsection{TeachMeets}

TeachMeets are open, informal, participant driven professional development events in the style of an 'unconference'. 
They provide an opportunity for teachers to share effective classroom practice with their peers in a comfortable, non-threatening environment. Practice typically focuses on the use of technology, but often straddles primary and secondary education, and all subject areas. TeachMeets represent an emerging trend of 'bottom-up' CPD, where teachers organise and facilitate an event, rather than have it led by an external expert. Anyone can set up a TeachMeet via the associated wiki (http://teachmeet.pbworks.com in the UK). Participants can then volunteer to make a short presentation, usually 2 or 7 minutes in length, or simply sign up to attend the event. There is no charge to participate and some organisers seek sponsorship in order to provide refreshments or 'goodie bags' to those attending. The exact format can vary from event to event, however some core features appear throughout: presentations must focus on classroom practice, as opposed to pitching a product; presenters are selected at random from those who volunteered; events are often streamed on the internet for those unable to make it in person; and a 'back-channel' is usually setup via Twitter, enabling participants to comment on presentations, share further ideas and make connections with others in attendance. The informality is sometimes reinforced by the humorous threat of 'being camelled' (having a stuffed toy camel thrown at you) if you don't adhere to the classroom practice focus or over-run your allocated time. Key to TeachMeets is that everyone present is equal; it is about practitioners sharing their expertise with each other.

Vital quickly recognised the power of TeachMeets and by February 2010 had incorporated them into its model of collaborative CPD, going on to directly support the running of well over 100 such events across England. The additional resources Vital could offer, including sponsorship, organisational support, filming and sharing events live or via the website played "a key role in establishing and developing the movement in English schools" (Dixon, 2013, p. 24).

\subsection{TeachShares}

Having witnessed the success of TeachMeets, Vital sought to leverage technology to bring the key elements of such events to a wider community. As a result, in May 2010 Vital designed and launched TeachShares. These involved using a video conferencing system, Elluminate Live! (subsequently Blackboard Collaborate) that enabled practitioners to provide a live demonstration of innovations in their teaching practice. It quickly became clear that having multiple presenters within a TeachShare was impractical because of the technical barriers of swapping between presentations. Thus rather than a number of short presentations as in a TeachMeet, TeachShares typically focused on one 15 minute presentation. One of the criticisms of TeachMeets is that they don't provide sufficient opportunity for discussion after each presentation, so TeachShares were designed to have a discussion session following on from the presentation. As TeachShares were wholly online events, they were potentially accessible to a much wider audience, not being bound by the constraints of place. Sessions were typically held after school hours, when practitioners could log in from home or school, without the need to change their routines, source cover for classes or organise childcare. This was particularly important in the light of a new policy known as 'Rarely Cover'. Rarely Cover (from September 2009) restricted the degree to which teachers could be asked to provide cover for other teaching staff. This resulted in teachers struggling to get released from their classrooms in order to attend staff development during the school day (House of Commons Children, Schools and Families Committee, 2010). TeachShares were also recorded so they could be downloaded and used by those unable to attend the live session.

Vital went on to host over 150 TeachShares, with an average of 15 participants per session. Whilst over $40 \%$ of these sessions focused on learning and teaching using digital technology, the areas covered began to broaden, encompassing other aspects of classroom practice (e.g. Story telling; Numeracy across the curriculum) as well as other whole-school issues (e.g. Leading from the middle; Building links with other schools). As the model became more established, TeachShares became a useful tool for practitioners to respond to and address areas of practice that were the focus of government scrutiny. For example, following a pilot in 300 primary schools in England in June 2011, the Department for Education announced the introduction of a statutory phonics screening check for all pupils in Year 1 (DfE, 2011). The flexibility and online nature of the TeachShare model meant that a series of Vital TeachShares ('Mr Thorne does phonics') could be quickly developed and shared with a wide audience. To date over 2,000 individuals have attended TeachShare sessions, with a further 2,200 copies of the recordings having been downloaded.

The TeachShare model was adopted by Computing at School (CAS, http://www.computingatschool.org.uk/), a subject association that promotes the teaching of computer science at school. CAS have incorporated the TeachShare model into their new DfE-funded professional development programme, the Network of Excellence, to provide training opportunities for new and existing computer science teachers. Vital initially provided their video conferencing infrastructure freely to CAS and trained key members to use it. 
"It's a brilliant communications mechanism for us [CAS]... a great way for teachers to keep up with important new developments like Raspberry Pi (Note 1). It generated great 'buzz' when we then talked to students about it - they saw their teacher as committed and bang up to date"

Kevin Jones, CAS TeachShare coordinator \& Computing teacher, June 2012

\subsection{Personal Learning Networks}

In the latter half of Phase 1 it had become increasingly clear that 'bite-size', targeted, readily accessible and informal professional development was proving significantly more successful than the original formal course-based offerings. From September 2010 Vital moved towards extending its work in this area, focusing on supporting practitioners in developing Personal Learning Networks (PLNs).

A Personal Learning Network (PLN) is an informal network of connections, linking a learner with people, tools and resources from which they can derive information and advice. PLNs are not a new concept, but where once they may have been made up of friends, colleagues and professional publications, technology has greatly expanded the possibilities. The Internet, social media, blogs, wikis and other tools have enabled educators to develop truly personalised networks, connecting with peers and other experts across the globe on a variety of levels, in their particular areas of interest. Siemens (2005) argues that these connections are at the heart of the matter, that knowledge is distributed across a network of connections, and therefore that learning consists of the ability to construct and traverse those networks. This kind of informal 'bottom-up' professional development puts the teacher at the heart of their own learning, in control of what, where and how they learn, and driven by their own motivations.

Alongside the TeachMeets and TeachShares, Vital developed a range of other offerings and services to support teachers in recognising the importance of PLNs and in developing their own. Initially this happened within the website, however the role of social media as a learning tool grew and Vital fostered a significant presence on Twitter, introducing the well-established hashtag \#vitalCPD and attracting thousands of followers. Twitter became an important means for sharing teaching ideas and news, developing connections and supporting teachers in becoming more active online.

Vital's regional teams worked closely with schools and local authorities to offer personalised online and face-to-face support, helping them to engage effectively with tools and resources that could support the development of learning networks amongst staff in their institutions. Subject-specific 'Top Tips' newsletters were shared on a weekly basis. These focused on providing information and advice about how to use a wide range of freely available software and resources to enhance ICT and the teaching of Computing. The 'Top Tips' proved very successful and were a forerunner of the Subject and Special Interest Portals developed during Phase 2.

\subsection{Outcomes}

Whilst Vital's courses did not recruit well, overall engagement with the website, and through social media, newsletters, referrals to other providers, and face to face events increased substantially, enabling Vital to exceed its target of providing the equivalent of 25,000 'training days' (Note 2). This pointed to the value of informal practiced-based learning networks to support professional development within Vital (Bradshaw et al., 2011; Walsh et al., 2011), which reinforced similar findings by Hanreats, Hulsebosch \& Laat (2011).

However, May 2010 had seen the formation of a new Conservative-Liberal Democrat coalition government, with the Department for Education (DfE) replacing the DCSF. The change in government was rapidly followed by significant changes in education policy and reductions in support for digital technology in schools. For example, ring fenced funding (the Harnessing Technology Grant) was cut, the government agency responsible for advising schools about digital technology (Becta) was closed, and the Building Schools for the Future programme, which included significant levels of funding for digital technology and professional development, was terminated.

Thus the climate was not conducive to a mindset that teaching is not effective without ICT, which Ertmer \& Ottenbreit-Leftwich (2010) argued was essential for successful embedding of digital technology in education. Nor for encouraging teachers to engage with knowledge that goes beyond what is essential in order to teach effectively in traditional classrooms, which Law (2008) argued was necessary in order to use digital technology in ways that changed practice, as Vital aimed to do.

In November 2010 the DfE published a white paper (DfE, 2010) that laid out a series of reforms to the schools system, with a shift away from central Government and Local Authorities towards devolved funding and responsibility for schools. Whilst this white paper recognised the importance of CPD, and the value sharing of expertise between practitioners (which mapped well onto Vital's model) it also proposed the establishment of 
Teaching Schools as centres of excellence that would become the main focus for CPD provision to their local school networks. Thus it came as a surprise when in late February 2011 Vital was awarded £2.5million by the DfE to extend the programme for one year, with a hint that there might be a further tranche of funding in the following year.

\section{Phase 2: Going Commercial (Apr 2011 - Mar 2012)}

The Vital Programme had been in the process of winding down prior to the late announcement of funding for Phase 2. This meant that much of the momentum had been lost. The second round of funding also equated to a cut of $£ 500,000$ in the annual budget relative to Phase 1b. One of the immediate changes was a reduction in the size of the Vital team, including reducing the number of staff based in the regions. In effect this meant moving from supporting nine regions to supporting 6 larger regions. Thus, whilst there was every indication that Vital had the potential to become a valuable hub for ICT CPD in a very changed landscape (Dixon, 2013), the changing circumstances combined with a desire to extend Vital's impact to teachers who were 'harder to reach', resulted in some significant changes to the project's key performance indicators (KPIs) and provision. Whereas in Phase 1 Vital's KPIs were focused on collaborating with other providers and delivering professional development ('training days') to teachers, in Phase 2 four of the five KPIs were linked to the sale of services and developing a robust business model. KPI 5 remained focussed on Vital's impact on practice (Guskey Level 4).

\subsection{Developing a Robust Business Model}

The imperative to develop a robust business model reflected an expectation that DfE funding for Vital would, at best, be extended for one more additional year, but at a reduced rate compared with Phase 2. Given the disruption caused by the need to restructure Vital's staffing due to the $£ 500000$ reduction in funding between Phase 1a and Phase 2 the team were keen to avoid a similar overall cut in funding the following year. Thus, there was an imperative for Vital to generate income in Phase 2, which would make good any cut in funding the following year, and ultimately would enable Vital to be totally self-funding. Consequently, Vital needed to develop provision that would generate quite substantial levels of income and a business plan to show how it could become self-funding over the medium term. This changed Vital's position from being a collaborator with, and supporter of, other providers, to being "just another competitor" (to quote the CEO of another CPD provider).

This was at a time of significant change and uncertainty for schools. The majority of CPD available to schools in England had previously come via their LA, and often (from the school's perspective) at little or no cost because it was free at the point of use. The shift in funding from LAs to schools, alongside other policy changes, had several significant impacts:

- many LA staff were made redundant and started to offer their services as independent CPD consultants at the same time as the Teaching Schools were starting to offer CPD, so that there was a surplus of CPD provision and confusion about where to turn for quality support;

- schools found themselves having to pay for many services which previously had appeared to be free (because they were provided by the LAs) and were uncertain about what their new budgets could afford, and so only spent money on 'essentials', which often didn't include CPD;

- schools were uncertain about the importance that they should place on ICT and computing, given the cuts in funding for digital technology and lack of any strategic guidance, and so were reluctant to spend money on digital technology or related CPD.

In 2012 the situation became even more challenging following the Minister for Education's statement that, "ICT in schools is a mess" and proposal that the National Curriculum for ICT [Computing] should be suspended with a view to implementing a rigorous computer science curriculum (Gove, 2012). These changes were accompanied by new rules on how DfE money could be spent, which meant that Vital's ability to market its provision was significantly reduced.

Within this turbulent landscape Vital developed and attempted to sell a new CPD offering that both addressed the changing context, and provided the programme with an opportunity to become self-funding.

\subsection{New Website with Subject and Special Interest Portals}

The second half of Phase $1 \mathrm{~b}$ had seen success working directly with teachers (rather than through LAs) in supporting TeachMeets, TeachShares and the development of PLNs. Vital recognised that this teacher-focused, bottom-up model of professional development was one that should be continued and extended. However, with the change in focus towards self-funding came the need to turn this model into a potential revenue stream. This resulted in a 
reconceptualisation of the website: moving away from a community website containing content (of varying quality which was difficult to navigate) contributed by members to a quality controlled 'published' website. This required a move from the original Moodle based infrastructure to a full content management system (Drupal), which enabled much greater functionality and control over the look and feel of the content offered.

Vital's work during Phase 1 had identified that there were a wide range of freely available digital technology tools and resources available on the Internet to support learning and teaching. Yet it was evident that teachers lacked the time to find and evaluate these resources, and needed help planning how to use them effectively in their own classrooms. The website was redesigned to include Subject and Special interest Portals, which were designed to meet these needs, and would be available on an annual subscription.

The Vital Portals were subject-focused, and provided teachers with an easily accessible route to a wealth of quality controlled information about subject specific resources. The focus was not on the creation of new content, but instead on expert guidance on the best available online resources and as to how to make the most effective use of them in order to motivate students and enhance learning. Professional development has been criticised for treating teachers as being homogeneous, ignoring their socio-economic context, age level, subject specialism and prior experience (Twining, Raffaghelli, Albion \& Knezek, 2013). The portals were designed to make it easy for busy teachers to find high quality peer-reviewed resources and information that was directly relevant to them and which they could immediately try out in their own practice.

Seven portals were launched in September 2011, with a further four by December the same year. Each was maintained and updated on a weekly basis by an experienced educator who was a specialist in their particular field.

The new website was launched in September 2011, and individual practitioners could purchase a subscription to the Portals. However, whilst meeting a need amongst the teaching community, the revenue from the Portals would not be sufficient to provide Vital with a sustainable business model and only met a subset of the features of effective CPD (see Table 7 in the 'Effective CPD?' section below). Thus Vital also developed a new school-focused offering, the In-house Professional Development Partnership (IPDP).

\subsection{The In-house Professional Development Programme (IPDP)}

The IPDP was a school-based professional development programme that provided cost-effective, sustainable staff development. It was flexible and adaptable, designed to align with a school's specific development priorities, and build leadership capacity, whilst also enhancing teachers' use of digital technology. The IPDP centred on the appointment and development of a Vital Professional (VP), a teacher or middle leader, who by working through the structured IPDP programme, became an in-school champion for both formal and informal professional development amongst their colleagues.

The IPDP was designed as a whole-school (or department) programme that required 'buy-in' from the school's senior management team in order to be effective. This reflects evidence about the importance of schools as the focus of professional development (Twining \& McCormick, 1999) and the importance of leadership in supporting change (Barnes \& Hall, 1998; Fullan, 1986; Hoffman, 1996; Hopkins, Ainscow \& West, 1994; Lieberman \& Miller, 1990; Louis \& Miles, 1990; Miles, Saxl \& Lieberman, 1988).

It was envisaged that the IPDP programme would take place over 3 school terms, ideally in one academic year. Initially the school was asked to identify their key priorities for development from their School Development Plan (SDP), and then to select a member of staff to become the Vital Professional (VP). The VP could be any member of staff with the capacity to become a leader amongst their colleagues and an advocate for effective CPD. Typically they might be a head of department, subject leader or advanced skills teacher.

The IPDP took the VP through a structured process, supported by a handbook, log, record sheets, a dedicated VP collaboration area in the website, and a range of short CPD modules. The programme was designed to be supported wholly online, primarily through the video conferencing system Blackboard Collaborate (previously known as Elluminate Live!).

Each VP could select any two modules to complete (see Table 5 overleaf). The selection depended on the needs of the individual VP as they worked through the programme to meet their school development target. The modules were unlike any course previously offered by Vital. Each was approximately 3 hours in length, made up of 1.5 hours of supported self-study using Vital's high quality materials, which prepared them to take part in a 1.5 hour tutorial via Collaborate. The tutorials were designed to enable participants to discuss specific issues arising from their self-study in the context of their particular school target(s). Once the module had been completed, the VP would go on to implement what they had learnt. 
The IPDP also included the provision of 20 Portal subscriptions. This was intended to enable the VP to support a team of colleagues in accessing new resources and trying them in their classrooms. The model aimed to build on the value of teacher cooperation and the need to ensure there was support at all levels within a school (Schulz-Zander \& Eickelmann, 2010).

During the initial design of the IPDP, feedback suggested that teachers would welcome some form of accreditation for completing the programme. The accreditation involved the VP in writing up a brief case study, structured around the Vital Practitioner Research Cycle, which a member of the school senior management team then endorsed to confirm it was accurate. Vital could then verify the information and issue a certificate to the VP.

Table 5. Summary of the IPDP Modules

\begin{tabular}{ll}
\hline Module Title & Summary of Content \\
\hline Exploring professional development & $\begin{array}{l}\text { Exploring the features of effective formal and informal } \\
\text { professional development and an introduction to Personal Learning } \\
\text { Networks. }\end{array}$ \\
$\begin{array}{l}\text { Finding and adapting resources } \\
\text { for your institution }\end{array}$ & $\begin{array}{l}\text { How to find and identify appropriate resources, and understand } \\
\text { how to use them effectively and legally in the school environment. }\end{array}$ \\
$\begin{array}{l}\text { Antroduction to organisational } \\
\text { needs analysis }\end{array}$ & $\begin{array}{l}\text { needs analysis, and an exploration of how to plan and carry out an } \\
\text { effective analysis in your school. }\end{array}$ \\
$\begin{array}{l}\text { Introduction to professional development } \\
\text { planning }\end{array}$ & $\begin{array}{l}\text { How to create an action plan for professional development using } \\
\text { SMART targets. }\end{array}$ \\
Introduction to Practitioner Research & $\begin{array}{l}\text { Exploring the power of practitioner research as a form of staff } \\
\text { development, and how to develop a small scale project in your } \\
\text { school. }\end{array}$ \\
$\begin{array}{l}\text { Introduction to running an effective } \\
\text { professional development event } \\
\text { Introduction to evaluating the impact of } \\
\text { professional development activities }\end{array}$ & $\begin{array}{l}\text { Events and how to set one up in your school. } \\
\text { Examing why evaluating the impact of CPD is important, and } \\
\text { how such an evaluation can be carried out in your school. }\end{array}$ \\
Introduction to peer coaching & $\begin{array}{l}\text { Exploring the differences between coaching and mentoring } \\
\text { colleagues and an examination of effective tools and techniques. }\end{array}$ \\
\hline
\end{tabular}

The IPDP was designed to include all of the features of effective CPD identified in the literature (see Table 7). Selling the IPDP became the primary focus of activity within Phase 2, aligning as it did with all five of Vital's KPIs in Phase 2.

\subsection{Research Evidence}

The Vital Practitioner Research Cycle continued to be an important element of Vital's model, but it had become clear that one of the barriers to teachers engaging with practitioner research was a lack of mechanisms for them to access and share evidence about their practice. This was exacerbated in relation to ICT with the reduction in available information and advice about the implementation of digital technology strategies in schools, which was caused by the demise of Becta and cuts in LAs.

Schools were also struggling with how to fund their digital technology requirements in a context in which a mobile technology revolution was taking place with the introduction of the iPad. So towards the end of Phase 2, Vital, in collaboration with the Knowledge Media Institute (KMi), started to develop an Evidence Hub that would help to build bridges between academic researchers, practitioner researchers, educational developers, and policy makers. The EdFutures Evidence Hub (http://edfutures.evidence-hub.net/) was based on the Open Education Evidence Hub (De Liddo, Buckingham-Shum, McAndrew, \& Farrow, 2012).

Vital also commissioned the National Foundation for Education Research (NFER) to carry out a survey to investigate teachers' views on a range of issues related to the use of mobile phones and social networks to inform its on-going provision. 


\subsection{Outcomes}

Vital invested a huge amount of resource in changing its Phase 1 approach in order to generate income and demonstrate that it had a robust business model in Phase 2. Feedback from teachers and schools confirmed the quality of the Portals and the IPDP (Dixon, 2013). For teachers, who were often overwhelmed with the mass of teaching resources available on the Internet and typically short on time, "the guidance offered [via the Subject Portals] by someone they recognised as a peer was powerful support" (Dixon, 2013, p. 39). This was reflected in Vital exceeding the target for sales of Portal subscriptions by a healthy margin. However, sales of the IPDP were disappointing. Whilst this reflected the challenging context within which the IPDP was launched, more significant factors appeared to relate to schools' planning cycles and the need for the IPDP to be integrated with a school's development plan. Schools in England work on an annual cycle, with decisions about CPD being made in the spring or early summer for provision the following academic year (i.e. from September to July). The launch of the IPDP missed this critical decision making window. Equally importantly, when schools buy a CPD service they want it to run for a whole academic year. Vital could only guarantee its provision for half the following academic year as its DfE funding ran until the end of March. Nonetheless, Vital demonstrated that it had a robust business model and only narrowly missed signing a contract with a commercial partner to move Vital from being a funded project to a self-funding business.

Vital's success in exceeding its KPIs in Phase 2 meant that the DfE agreed to provide another round of funding, of £1.25million, to take Vital into Phase 3.

\section{Phase 3 - Extending Impact (April 2012 - Mar 2013)}

The funding for Phase 3 represented a 50\% reduction relative to Phase 2, which required another redesign of Vital's staffing and provision. At this point it was also decided that trying to become self-funding had been counter-productive because it had positioned us as a competitor rather than a collaborator and had reduced teachers' access to our provision. Vital thus moved from having staff supporting six separate regions to having one team covering the whole of England. Our KPIs continued to be linked to sales of portal subscriptions and impact on practice. Whilst the three core areas of activity (IPDP, Portals and Research Evidence) continued, their relative importance changed as the focus shifted to developing an exit strategy that would ensure the maximum on-going impact of Vital's work once DfE funding had ended.

\subsection{Supporting the IPDP}

The IPDP was designed as a one-year programme. As Vital was unable to guarantee that it would be able to support the programme from April 2014 we stopped trying to sell the IPDP in Phase 3. The focus of all IPDP-related activity during Phase 3 shifted to supporting the existing partner schools, ensuring they gained maximum value from the programme. A member of staff was appointed to coordinate this activity and support schools through the process.

The IPDP Handbook, logs, record sheets, and all the module materials were converted into Open Educational Resources (OERs), for use independently of Vital, and made available via The Open University's OpenLearn website (http://labspace.open.ac.uk/course/category.php?id=53).

\subsection{Portal Bundles}

With the move away from becoming self-funding towards maximising impact and legacy, Vital decided to focus on extending the reach of the Portals. Three of the KPIs for this phase focused on achieving 1,000 additional paid subscribers to the portals, at least $20 \%$ of whom had to be from 'hard-to-reach' schools and $10 \%$ from each of Vital's Phase 2 regions. To meet this target, the Portal sales model was adapted, and 'bundles' of subscriptions (5, 10, 50 and 100) were sold at a discounted rate directly to schools and other organisations. The KPI targets were quickly exceeded, with over 1,500 additional subscriptions sold by the end of June 2012. As the 2012/13 school year began, the cost of subscriptions was reduced even further - in light of the programme likely coming to an end in March 2013.

\subsection{Research Evidence -EdFutures.net and Your Own Technology Survey (YOTS)}

Work on the EdFutures Evidence Hub rapidly evolved into the development of wiki called EdFutures.net (http://edfutures.net), through which teachers, academic researchers, and educational developers could collaborate, sharing information and discussing evidence about ICT.

The results of Vital's NFER survey (Aston \& Brzyska, 2012) highlighted teachers' concerns about the use of mobile phones in schools. Thus, EdFutures.net was seeded with information from reviews of the literature on digital 
technology strategies, with a particular focus on mobile technologies. However, there was a lack of evidence about strategies such as Bring Your Own Device (BYOD) or Bring Your Own Technology (BYOT). Vital therefore designed and commissioned 22 case studies focused on 'cutting edge' digital technology strategies related to the use of mobile devices. These case studies and their meta-analysis were designed to provide information and guidance to schools, via EdFutures.net, which would continue to be relevant even after DfE funding for Vital had ended.

Vital's NFER study had identified that $85 \%$ of teachers in secondary schools thought that many of their pupils had an Internet enabled mobile phone. However, as Vital's research on digital technology strategies progressed, one of the key issues that emerged was that schools lacked even basic information about their pupils' access to the Internet and Internet enabled mobile devices 'from home'. To help address this problem Vital developed a service for schools called YOTS (Your Own Technology Survey, http://www.yots.org.uk), which was launched in January 2013. YOTS provides schools with an easy way to audit their pupils' digital technology access at home and find out the proportion of pupils who have Internet enabled mobile devices that they would be allowed, able and willing to bring in to school on a regular basis.

\subsection{Sustainability}

From the start of Phase 3 a major focus was on how to ensure that Vital's work continued to have an impact after DfE funding ceased at the end of March 2013. Having already rejected becoming self-funding as an option an alternative approach to sustainability was needed.

The strategy that developed was to split Vital's provision into four discrete packages:

- Course and IPDP materials, which were made available on a Creative Commons Licence via the Open University's OpenLearn website (http://labspace.open.ac.uk/course/category.php?id=50)

- The Vital Brand and website (including the Portals), which were put out to open tender so that another provider could take them over

- EdFutures.net (and data from the 22 case studies), which would be retained and developed within the OU

- YOTS, which would be retained and developed within the OU

6.5 Outcomes (Phase 3 and beyond)

Despite considerable support for the IPDP only a small number of schools completed the full programme. However, the KPIs for Portal subscriptions were exceeded by a significant margin (e.g. nearly 7,300 more sales than the 1,000 target). Activity on the website and engagement with the portals grew quickly, in line with the sales.

Jisc Advance, a UK wide body that traditionally supported the use of digital technology in Higher and Further Education but wanted to break into the schools sector, won the tender for the Vital brand and website. In their bid they promised to continue to develop and extend the Portals for a minimum of two years, as a free service to teachers in England. Vital worked with Jisc Advance from November 2012 to ensure a smooth handover of the website at the end of March 2013.

The research methodology and tools used in Vital's 22 case studies were published in EdFutures.net (see http://edfutures.net/Research_Strategy and http://edfutures.net/Technology_Strategy_Case_Studies) and work started on the meta-analysis across the case studies. One of the outcomes from that meta-analysis was a set of 'emerging trends' evident in the case study schools which were mapped to the Mode dimension of the CPF. These trends spanned issues such as: funding (for digital technology); the model of digital technology provision; network infrastructure; management of digital technology; the model of CPD; the role of pupils, and the role of teachers (see http://edfutures.net/Digital_technology_trends).

At the end of March 2013 EdFutures.net and YOTS remained as part of the research of members of the Vital team who had on-going academic posts at the Open University. YOTS attracted funding from the Centre for Research in Education and Educational Technology (CREET) to extend its reach by developing localised versions of the website and survey. It is anticipated that YOTS will be available in the USA and Australia from Autumn 2013 with versions in French, Mandarin Chinese and Bangla being available in 2014.

The independent external evaluation of Vital (Dixon, 2013) concluded that, "In each of the 3 phases of the programme, Vital met its objectives and exceeded the challenging KPIs set." (p. 4) and went on to state that:

"The wider impact of Vital on the whole educational community will continue to be felt long after the project funding ceases through the continued development of the brand and Subject Portals by Jisc and as the newly developed EdFutures.net website and Your Own Technology Survey (YOTS) are further developed by Peter Twining to 
support teachers and schools in the implementation of technologies and new curricula in ICT."

(Dixon, 2013, p. 5)

\section{Effective CPD?}

In June 2011 Technical Working Groups 3 (TWG3), which consisted of 21 experts from 14 countries, held discussions on teacher professional development (TPD) related to ICT at EDUsummIT 2011. Twining et. al. (2013, p. 9) reporting on a review of the literature and these TWG3 discussions concluded that "one of the most significant 'findings' from the TWG3 discussions was that while many of the issues relating to effective TPD are not new, much TPD across the world continues to ignore them,". Vital explicitly set out to identify features of effective CPD to inform its provision. This provision changed significantly over the course of the programme, as summarised in Table 6. However, each incarnation was underpinned by two guiding principles:

- teachers are the experts in teaching and need to be supported in sharing that expertise

- the Vital Practitioner Research Cycle encapsulates the key elements of effective CPD identified within the literature.

Table 6. Overview of the Phases of Vital

\begin{tabular}{|c|c|c|c|c|}
\hline Phase 1a & Phase 1b & Phase 2 & Phase 3 & Post DfE funding \\
\hline July to Dec 09 & Jan 10 to Mar 11 & Apr 11 to Mar 12 & Apr 12 to Mar 13 & Apr 13 - \\
\hline$£ 2.65$ million & $£ 3.0$ million & $£ 2.5$ million & $£ 1.25$ million & $£ 0$ \\
\hline Regions & 9 & 6 & 1 & \\
\hline Drivers & Collaboration & Self-funding & Impact (legacy) & \\
\hline Key contacts & Local Authorities & Schools & Schools \& Policy & \\
\hline Website & Community & 'Published' & 'Published' & Jisc Advance \\
\hline Core offer & Courses & IPDP & Portals & \\
\hline $\begin{array}{l}\text { Othe key } \\
\text { provision }\end{array}$ & $\begin{array}{l}\text { TeachMeets } \\
\text { TeachShares } \\
\text { PLNs }\end{array}$ & $\begin{array}{l}\text { Portals } \\
\text { TeachShares }\end{array}$ & Research evidence & $\begin{array}{l}\text { EdFutures.net } \\
\text { YOTS }\end{array}$ \\
\hline
\end{tabular}

Analysis of the data from the Vital case studies suggested that there is a continuum in the models of CPD provision that schools may develop through, which is illustrated in Figure 5.

\section{Formal CPD Informal CPD Learning organisation}

Figure 5. The CPD ‘Emerging Trend’ (Twining, 2013a)

At the 'Formal CPD' end of the spectrum CPD is interpreted as 'taking a course'. Schools that fit into the 'Informal CPD' category recognise the value of a wider range of models of professional development, but tend not to have systems in place to maximise or evaluate their impact within the school community. Schools at the Learning organisation end of this continuum have a culture of continuous improvement and sharing, which recognises the professional status and expertise of teachers. This is often embedded in systems and processes to support practitioner research throughout the school. The IPDP was designed to enhance exactly this kind of systemic support, and analysis of the IPDP model (see Table 7) shows that it incorporates all of the key features of effective CPD identified in the original literature review (see 'Vital's proposed model of CPD (Early 2009)'). 
Table 7. Analysis of the Key Approaches Used within Vital vs Features of Effective CPD

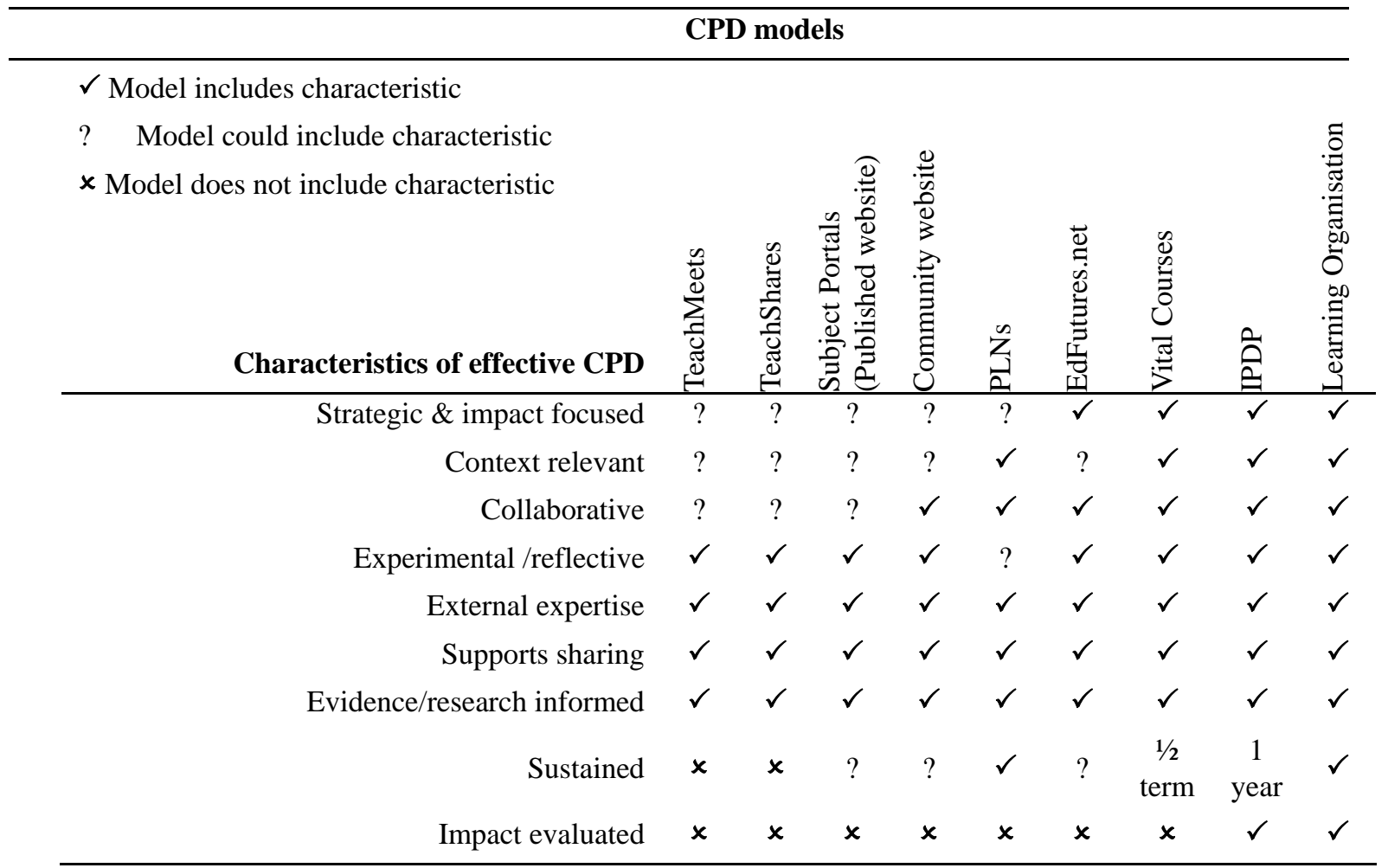

Based on the analysis summarised in Table 7 you would expect the IPDP to be the most effective model of CPD that Vital provided. However, it was clear that uptake of the IPDP (and Vital Courses) was substantially less than for the other approaches, which tended to lack a strategic and impact focus, were not necessarily sustained, and were not impact evaluated.

In thinking about effective CPD one needs to balance the features that make CPD effective against pragmatic constraints that impact on levels of teacher engagement or uptake. Some of these factors have been explicitly highlighted in the accounts of Phases 1 to 3, such as the importance of the school planning cycle. Others were implicit. For example, CPD that is 'more granular' (such as PLNs or using the Subject Portals) and thus fits better into teachers' busy lives is easier for teachers to engage with.

A key distinction between the different models is the extent to which they involved the senior management team in the school, rather than an individual teacher. You might frame this as whether they are 'top-down' or 'bottom-up'. Based on Vital's experience it is easier to engage teachers in 'bottom-up' CPD, such as TeachMeets, TeachShares and PLNs. While this might well impact significantly on individual teachers, it is unlikely to bring about changes at the organisational or system level. For that you need 'top-down' models, such as the IPDP, which requires long timescales, senior management commitment and close alignment with the school's own priorities. Ultimately, it is marrying together the 'top-down' with the 'bottom-up' to maximise strategic impact through exploration and sharing of evidence about 'what works' that is going to be the most effective.

The discussion so far has focussed on the English school system between 2009 and 2013. One has to question the extent to which this is relevant to other contexts, such as the school systems in other countries. Based on research on school systems worldwide, Barber and Mourshed (2007) concluded that:

"Clearly there are inevitable differences between schools: policy makers in Seoul, Helsinki and Chicago operate in completely different cultural and political contexts, and confront different challenges. ... Yet there were also fundamental similarities."(p.13)

They went on to identify some factors that high-performing school systems consistently all do, including:

- $\quad$ "They get the right people to become teachers (the quality of an education system cannot exceed the quality of its teachers), 
- They develop these people into effective instructors (the only way to improve outcomes is to improve instruction)."

(Barber \& Mourshed, 2007, p. 13)

Elmore (2004, quoted in Barber and Mourshed, 2007, p.27) stated that: "The notion that external ideas by themselves will result in changes in the classroom and school is deeply flawed as a theory of action". Barber and Mourshed (2007) found that providing differentiated support for teachers was critical and highlighted the four key approaches to professional development that high-performing school systems use:

- building practical skills during the initial training

- placing coaches in schools to support teachers

- $\quad$ selecting and developing effective instructional leaders

- $\quad$ enabling teachers to learn from each other

These all align well with Vital's findings about what is effective, and suggest that approaches to professional development that building learning organisations, which integrate top-down with bottom-up strategies of the kinds discussed here, are likely to work across contexts.

\section{References}

Aston, H., \& Brzyska, B. (2012). Protecting Children Online: Teachers’ perspectives on eSafety (Full report). Milton Keynes: $\quad$ Vital. $\quad$ Retrieved from http://www.nfer.ac.uk/nfer/publications/95001/95001_home.cfm?publicationID=658\&title=Protecting\%20Chil dren\%20Online:\%20Teachers’\%20perspectives\%20on\%20eSafety

Barber, M., \& Mourshed, M. (2007). How the world's best-performing school systems come out on top (p. 56). London: McKindsey and Company.

Barnes, W. G. W., \& Hall, C. R. (1998). Seven Stars that Shine or Seven Tacks to Step On: Making technology in-service programs work. In D. S. Niederhauser \& N. Strudler (Eds.), SITE 98. Washington DC: Association for the Advancement of Computing in Education (ACCE).

Barton, B. (2009, September). Technology in UK education - history and the future. Retrieved from https://www.google.co.uk/url?sa=t\&rct=j\&q=\&esrc=s\&source=web\&cd=1\&ved=0CDYQFjAA\&url=http\%3A \%2F\%2Fwww.keystone-education.co.uk\%2Fwp-content\%2Fuploads\%2F2011\%2F01\%2FTechnology-in-UKEducation-2.doc\&ei=ki7EUZqKO8GX1AXIu4CwBg\&usg=AFQjCNGXpUisfrIhKWY1j0w1R1XfA1HouA

Baumfield, V., Hall, E., \& Wall, K. (2008). Action research in the classroom. London: SAGE.

Bell, B., \& Gilbert, J. K. (1996). Teacher Development: A Model From Science Education. Routledge.

Belland, B. R. (2009). Using the theory of habitus to move beyond the study of barriers to technology integration. Computers \& Education, 52(2), 353-364. http://dx.doi.org/10.1016/j.compedu.2008.09.004

BESA. (2009). ICT provision \& use in 2009/10 (p. 6). London: BESA.

Bolam, R. (2000). Emerging policy trends: some implications for continuing professional development. Journal of In-Service Education, 26(2), 267-280. http://dx.doi.org/10.1080/13674580000200113

Borko, H., Whitcomb, J., \& Liston, D. (2008). Wicked Problems and Other Thoughts on Issues of Technology and Teacher Learning. Journal of Teacher Education, 60(1), 3-7. http://dx.doi.org/10.1177/0022487108328488

Bradshaw, P., Twining, P., \& Walsh, C. (2011). The vital program: transforming ICT professional development. American Journal of Distance Education, 26(2), 74-85. Retrieved from http://oro.open.ac.uk/29086/1/ICICTE2011Bradshaw_Twining_Walsh_06902_April21.doc

Cloke, C. (2000). Planning to use ICT, factors which influence teachers. ESRC ICT \& Pedagogy.

Cochran-Smith, M., \& Lytle, S. L. (1999). The Teacher Research Movement: A Decade Later. Educational Researcher, 28(7), 15-25. http://dx.doi.org/10.3102/0013189X028007015

Condie, R., \& Livingston, K. (2007). Blending online learning with traditional approaches: changing practices. British Journal of Educational Technology, 38(2), 337-348. http://dx.doi.org/10.1111/j.1467-8535.2006.00630.x 
Coolahan, J. (2002). Teacher Education and the Teaching Career in an Era of Lifelong Learning (OECD Education Working Papers). Paris: Organisation for Economic Co-operation and Development. Retrieved from http://www.oecd-ilibrary.org/content/workingpaper/226408628504

Coolahan, J. (2005). The primary school curriculum: current context, emerging issues and future challenges. Presented at the The primary curriculum in schools. Dublin: Department of Education and Science and the Natinoal Council for Curriculum and Assessment.

Cordingley, P., Bell, M., Isham, C., Evans, D., \& Firth, A. (2007). Continuing Professional Development: What do specialists do in CPD Programmes for which there is evidence of positive outcomes for pupils and teachers? (No. 1504R). London: EPPI-Centre. Retrieved from http://eppi.ioe.ac.uk/cms/LinkClick.aspx?fileticket=27_OKOKeWnI\%3D\&tabid=2307\&mid=4267

Cuban, L. (1993). Computers meet classroom: Classroom wins. Teachers College Record, 95(2), 185 (26p). Retrieved from http://ehostvgw1.epnet.com/ehost.asp?key=204.179.122.141_8000_854850066\&site=ehost\&return=n

Cuban, L. (2001). Oversold and Underused: Computers in the Classroom. London: Harvard University Press. Retrieved from http://www.hup.harvard.edu/catalog/CUBOVE.html

Culp, K. M., Honey, M., \& Mandinach, E. (2005). A Retrospective on Twenty Years of Education Technology Policy. Journal of Educational Computing Research, 32(3), 279-307. Retrieved from http://libezproxy.open.ac.uk/login?url=http://search.ebscohost.com/login.aspx?direct=true\&db=ehh\&AN=1830 3117\&site $=$ ehost-live \&scope $=$ site

Daly, C., Pachler, N., \& Pelletier, C. (2009a). Continuing Professional Development in ICT for teachers: A literature review (No. A literature review) (p. 47). Coventry: Becta. Retrieved from http://www.wlecentre.ac.uk/cms/files/becta/becta-ict-cpd-literaturereview.pdf

Daly, C., Pachler, N., \& Pelletier, C. (2009b). Continuing Professional Development in ICT for teachers (No. 2) (p. 47). Coventry: Becta. Retrieved from http://www.wlecentre.ac.uk/cms/files/becta/becta-ict-cpd-report.pdf

Davis, N., Preston, C., \& Sahin, I. (2009). Training teachers to use new technologies impacts multiple ecologies: Evidence from a national initiative. British Journal of Educational Technology, 40(5), 861-878. http://dx.doi.org/10.1111/j.1467-8535.2008.00875.x

De Liddo, A., Buckingham-Shum, S., McAndrew, P., \& Farrow, R. (2012). The open education evidence hub: a collective intelligence tool for evidence based policy. Presented at the Cambridge 2012: Joint OER12 and OpenCourseWare Consortium Global 2012 Conference, Cambridge, UK.

DfE. (2010). The importance of teaching. London: Stationery Office. Retrieved from http://www.official-documents.gov.uk/document/cm79/7980/7980.asp

DfE. (2011, June). The Department for Education. Retrieved June 26, 2013, from http://www.education.gov.uk/emailer/schools/teachingandlearning/pedagogy/a00197709/developing-a-new-yea r-1-phonics-screening-check?if=1

DfE. (2013). Consultation on computing and disapplication - Schools. Retrieved June 21, 2013, from https://www.education.gov.uk/schools/teachingandlearning/curriculum/nationalcurriculum2014/a00224578/con sultation

DfES. (2002a). The School Of The Future Will Radically Transform Learning. London: HMSO.

DfES. (2002b). Transforming the way we learn: A vision for the future of ICT in schools (p. 28). London: HMSO.

DfES. (2003). Fulfilling the Potential: Transforming teaching and learning through ICT in schools. London: HMSO.

DfES. (2005). Harnessing Technology: Transforming Learning and Children's Services. London: HMSO.

Dixon, G. (2013). Vital external evaluation report on KPI 5: Impact (p. 84). Milton Keynes: Propensity Ltd.

Dwyer, D. C., Ringstaff, C., \& Sandholtz, J. H. (1990). Teacher Beliefs and Practices Part I: Patterns of Change. The Evolution of Teachers' Instructional Beliefs and Practices in High-Access-to-Technology Classrooms. First to fourth year findings. Cupertino: Apple Computer Inc.

Elmore, R. F. (2000). Building a new structure for school leadership. Washington, D.C.: The Albert Shanker Institue. Retrieved from http://www.politicalscience.uncc.edu/godwink/PPOL8687/Wk10\%20March\%2022\%20Accountability/Elmore 
\%20Building\%20a\%20New\%20Structure\%20for\%20Leadership.pdf

Ertmer, P. A. (2005). Teacher Pedagogical Beliefs: The Final Frontier in Our Quest for Technology Integration? Educational Technology Research \& Development, 53(4), 25-39. Retrieved from http://libezproxy.open.ac.uk/login?url=http://search.ebscohost.com/login.aspx?direct=true\&db=a9h\&AN=1951 $1442 \&$ site $=$ eds-live $\&$ scope $=$ site

Ertmer, P. A., \& Ottenbreit-Leftwich, A. T. (2010). Teacher Technology Change: How Knowledge, Confidence, Beliefs, and Culture Intersect. Journal of Research on Technology in Education, 42(3), 255-284. Retrieved from

http://libezproxy.open.ac.uk/login?url=http://search.ebscohost.com/login.aspx?direct=true\&db=eric\&AN=EJ88 2506\&site=eds-live\&scope=site

Fraser, C., Kennedy, A., Reid, L., \& Mckinney, S. (2007). Teachers’ continuing professional development: contested concepts, understandings and models. Journal of In-Service Education, 33(2), 153-169. http://dx.doi.org/10.1080/13674580701292913

Fullan, M G. (1986). Improving the implementation of educational change. School Organization, 6(3), 321-326.

Fullan, Michael G. (1990). Staff development, innovation, and institutional development. In B. Joyce (Ed.), Changing school culture through staff development. Alexandria, Virginia: Association for Supervision and Curriculum Development. Retrieved from http://eric.ed.gov/?id=ED315919

Goodliff, G., \& Twining, P. (2008). Computer mediated communication: using e-learning to support professional development. In L. Miller \& C. Cable (Eds.), Professionalism in the early years (pp. 98-108). London: Hodder Arnold.

Gove, M. (2012, January). Michael Gove speech at the BETT Show 2012 - Speeches - Inside Government GOV.UK. $\quad$ Retrieved June 26, from https://www.gov.uk/government/speeches/michael-gove-speech-at-the-bett-show-2012

Guskey, T. (2002). Professional Development and Teacher Change. Teachers and Teaching, 8(3), 381-391. http://dx.doi.org/10.1080/135406002100000512

Guskey, T. R. (2000). Evaluating Professional Development. Corwin Press.

Hall, E. (2009). Engaging in and engaging with research: teacher inquiry and development. Teachers \& Teaching, 15(6), 669-681. http://dx.doi.org/10.1080/13540600903356985

Hanraets, I., Hulsebosch, J., \& de Laat, M. (2011). Experiences of pioneers facilitating teacher networks for professional development. Educational Media International, 48(2), 85-99. http://dx.doi.org/10.1080/09523987.2011.576513

Hargreaves, A. (1994). Changing Teachers, Changing Times: Teachers' Work and Culture in the Postmodern Age. Continuum.

Hargreaves, A. (2010). Presentism, Individualism, and Conservatism: The Legacy of Dan Lortie's Schoolteacher: A Sociological Study. Curriculum Inquiry, 40(1), 143-154. http://dx.doi.org/10.1111/j.1467-873X.2009.00472.x

Harris, S. (1999). INSET for IT: a review of the literature relating to preparation for and use of IT in schools (p. 53). Slough: National Foundation for Educational Research.

Haydn, T., \& Barton, R. (2007). "First do no harm": developing teachers' ability to use ICT in subject teaching: some lessons from the UK. British Journal of Educational Technology, 38(2), 365-368. http://dx.doi.org/10.1111/j.1467-8535.2006.00639.x

Heider, K. (2005). Teacher isolation: how mentoring programs can help. Current Issues in Education, 8(14). Retrieved from http://cie.asu.edu/volume8/number14/index.html

Hexel, D., De Marcellus, O., \& Bernoulli, M. (1998). Potentials and constraints of ICT in schools. Educational Media International, 35(3), 149-156.

Hoffman, B. (1996). What Drives Successful Technology Planning? Journal of Information Technology for Teacher Education, 5(1/2), 43-55.

Hollingworth, S., Allen, K., Hutchings, M., Kuyok, K. A., \& Williams, K. (2008). Technology and school improvement: reducing social inequity with technology? (p. 124). Coventry: Becta. Retrieved from http://www.londonmet.ac.uk/fms/MRSite/Research/ipse/BECTa\%20school_improvement_final_report.pdf 
Hopkins, D., Ainscow, M., \& West, M. (1994). School Improvement in an Era of Change. Continuum International Publishing Group Ltd.

Horne, J. (2010, June 18). Open University learning is a joy. The Guardian. Retrieved from http://www.guardian.co.uk/commentisfree/2010/jun/18/open-university-learning-joy

Kennedy, A. (2005). Models of Continuing Professional Development: a framework for analysis. Journal of In-Service Education, 31(2), 235-250. http://dx.doi.org/10.1080/13674580500200277

Kozma, R. B. (2003b). Technology and Classroom Practices: An International Study. Journal of Research on Technology in Education, 36(1), 1-14. Retrieved from http://libezproxy.open.ac.uk/login?url=http://search.ebscohost.com/login.aspx?direct=true\&db=bth\&AN=11950 $622 \&$ site $=$ eds-live $\&$ scope $=$ site

Kozma, R. B. (Ed.). (2003a). ICT and educational change: a global phenomenon. In Technology, Innovation, and Educational Change: A Global Perspective (pp. 1-18). Eugene, Oregon: International Society for Technology in Educa.

Lave, J., \& Wenger, E. (1991). Situated Learning: Legitimate Peripheral Participation. Cambridge University Press.

Law, N. (2008). IT, pedagogical innovations, and teacher learning. In J. Voogt \& G. Knezek (Eds.), International Handbook of Information Technology in Primary and Secondary Education (pp. 421-423). New York: Springer.

Lieberman, A., \& Miller, L. (1990). Restructuring Schools: What Matters and What Works. Phi Delta Kappan, 71(10), 759-764.

Lieberman, A., \& Pointer Mace, D. (2010). Making Practice Public: Teacher Learning in the 21st Century. Journal of Teacher Education, 61(1-2), 77-88.

Looi, C. K., Lim, W. Y., \& Chen, W. (2008). Communities of practice for continuing professional development in the Twenty-first Century. In J. Voogt \& G. Knezek (Eds.), International Handbook of Information Technology in Primary and Secondary Education (pp. 489-502). New York: Springer.

Lortie, D. C. (2002). Schoolteacher: a sociological study (Second.). Chicago: University of Chicago Press.

Louis, K. S., \& Miles, M. B. (1990). Improving the Urban High School: What Works and Why. New York: Teachers College Press.

Luckin, R., Bligh, B., Manches, A., Ainsworth, S., Crook, C., \& Noss, R. (2012). Decoding Learning: the proof, promise and potential of digital education. London: Nesta. Retrieved from http://www.nesta.org.uk/areas_of_work/public_services_lab/digital_education/assets/features/decoding_learnin g_report

McCormick, R., Banks, F., Morgan, B., Opfer, D., Pedder, D., Storey, A., \& Wolfenden, F. (2008). Schools and continuing professional development (CPD) in England - State of the Nation research project: Literature review. London: TDA.

Miles, M. B., Saxl, E. R., \& Lieberman, A. (1988). What Skills Do Educational "Change Agents” Need? An Empirical View. Curriculum Inquiry, 18(2), 157-193.

Mishra, P., \& Koehler, M. J. (2006). Technological Pedagogical Content Knowledge: A Framework for Teacher Knowledge. Teachers College Record, 108(6), 1017-1054. Retrieved from http://www.tcrecord.org.libezproxy.open.ac.uk/library/content.asp?contentid=12516

Moseley, D., Higgins, S., Bramald, R., Hardman, F., Miller, J., Mroz, M., ... Stout, J. (1999). Ways forward with ICT: Effective pedagogy using Information and Communications Technology for Literacy and Numeracy in Primary Schools. Newcastle: University of Newcastle.

Murchan, D., Loxley, A., \& Johnston, K. (2009). Teacher learning and policy intention: selected findings from an evaluation of a large-scale programme of professional development in the Republic of Ireland. European Journal of Teacher Education, 32(4), 455-471. http://dx.doi.org/10.1080/02619760903247292

OECD. (1998). Staying Ahead: In-service Training and Teacher Professional Development. Paris: OECD.

OECD. (2009). Creating Effective Teaching and Learning Environments: First Results from TALIS. Retrieved June 19, 2013, from http://www.oecd.org/fr/edu/scolaire/creatingeffectiveteachingandlearningenvironmentsfirstresultsfromtalis.htm 
Ofsted. (2006). The logical chain: continuing professional development in effective schools. London: Ofsted. Retrieved from http://www.ofsted.gov.uk/resources/logical-chain-continuing-professional-development-effective-schools-0

Opfer, D., Pedder, D., \& Lavicza, Z. (2008). Schools and continuing professional development (CPD) in England State of the Nation research project: Survey report. London: TDA.

Pedder, D., Storey, A., \& Opfer, D. (2008). Schools and continuing professional development (CPD) in England State of the Nation research project: Synthesis report. London: TDA. Retrieved from http://www.tda.gov.uk/upload/resources/pdf/c/cpd_stateofthenation_report.pdfSynthesis report

Pelgrum, W., \& Plomp, T. (1991). The Use of Computers in Education Worldwide. Oxford: Pergamon Press.

Rivkin, S. G., Hanushek, E. A., \& Kain, J. F. (2005). Teachers, Schools, and Academic Achievement. Econometrica, 73(2), 417-458. http://dx.doi.org/10.2307/3598793

Scheerens, J. (2010). Teachers' professional development - Europe in international comparison: an analysis of teachers' professional development based on the OECD's Teaching and Learning International Survey (TALIS). Luxembourg: Office for Official Publications of the European Union. Retrieved from http://ec.europa.eu/education/school-education/doc/talis/report_en.pdf

Schulz-Zander, R., \& Eickelmann, B. (2010). Teacher Professional Development - An Empirical Analysis of ICT-related Teacher Cooperation from a School Improvement Perspective. Society for Information Technology \& Teacher Education International Conference 2010, 2010(1), 1626-1632. Retrieved from http://editlib.org/p/33590

Selwood, I., \& Twining, P. (2005). Action Research (p. 11). Coventry: Becta.

Shulman, L. S. (1986). Those who understand: Knowledge growth in teaching. Educational Researcher, 15(2), 4-14.

Siemens, G. (2005). Connectivism: a learning theory for the Digital Age. Journal of Instructional Technology and Distance Learning, 2(1), 3-10.

Somekh, B. (2008). Factors affecting teachers' pedagogical adoption of ICT. In J. Voogt \& G. Knezek (Eds.), International Handbook of Information Technology in Primary and Secondary Education (pp. 449-460). New York: Springer.

Stenhouse, L. (1979). Research as a basis for teaching. Inaugural lecture, University of East Anglia.

Trend, R., Davis, N., \& Loveless, A. (1999). Information and Communications Technology. London: Letts Education.

Twining, P., Raffaghelli, J., Albion, P., \& Knezek, D. (2013). Moving education into the digital age: the contribution of teachers' professional development: Moving education into the digital age. Journal of Computer Assisted Learning, n/a-n/a. http://dx.doi.org/10.1111/jcal.12031

Twining, Peter, \& Footring, S. (2010). The Schome Park Programme: exploring educational alternatives. In A. Peachey, J. Gillen, D. Livingstone, \& S. Smith-Robbins (Eds.), Researching learning in virtual worlds (1st ed., pp. 53-74). New York: Springer. http://www.springer.com/computer/general+issues/book/978-1-84996-046-5

Twining, Peter, \& McCormick, R. (1999). Learning Schools Programme: developing teachers' information communication technology competence in the support of learning. In C. Crawford, D. Willis, R. Carlsen, I. Gibson, K. McFerrin, J. Price, \& R. Weber (Eds.), Proceedings of Society for Information Technology and Teacher Education International Conference 1999 (pp. 1703-1708). Chesapeake (VA): AACE.

Twining, Peter, Raffaghelli, J., Albion, P., \& Knezek, D. (2013). Moving Education into the Digital Age: The Contribution of Teachers' Professional Development. Journal of Computer Assisted Learning, In Press. http://dx.doi.org/10.1111/jcal.12031

Twining, Peter. (2001a). Planning to use ICT in schools? Education 3-13, 29(1), 9-17.

Twining, Peter. (2001b). E211 Learning Matters: Challenges of the Information Age - Software Guide. Milton Keynes: The Open University.

Twining, Peter. (2002a). Enhancing the Impact of Investments in "Educational” ICT (PhD Thesis). The Open University, Milton Keynes. Retrieved from http://kn.open.ac.uk/public/document.cfm?documentid=2515 
Twining, Peter. (2002b). Conceptualising Computer Use in Education: introducing the Computer Practice Framework (CPF). British Educational Research Journal, 28(1), 95-110. http://dx.doi.org/10.1080/01411920120109775

Twining, Peter. (2003). dICTatEd - Discussing ICT, Aspirations and Targets for Education: Overview of responses up to 30th June 2003 (No. meD8-03-02). Milton Keynes: meD8. Retrieved from http://kn.open.ac.uk/public/document.cfm?documentid=2946 (visited 29.4.03)

Twining, Peter. (2008). Framing IT use to enhance educational impact on a school-wide basis. In J. Voogt \& G. Knezek (Eds.), International Handbook of Information Technology in Primary and Secondary Education (pp. 555-577). New York: Springer.

Twining, Peter. (2010). When educational worlds collide. In Virtual Worlds: controversies at the frontiers of education (pp. 125-142). New York: Nova Science Publishers.

Twining, Peter. (2013a). Digital technology trends (EdFutures.net). Milton Keynes: EdFutures.net. Retrieved from http://edfutures.net/Digital_technology_trends

Twining, Peter. (2013b, May 4). ICT is dead - long live ICT. PeterT's bliki. wiki. Retrieved from http://edfutures.net/ICT_is_dead_-_long_live_ICT

Walsh, C. S., Bradshaw, P., \& Twining, P. (2011). e-learning through collaborative teacher professional development in primary and secondary schools in England. IADIS International Conference eLearning 2011. Retrieved from http://www.elearning-conf.org/Program_EL2011.pdf\#page=5

\section{Notes}

Note 1. The Raspberry Pi is a low-cost, credit card sized single board computer with high performance video and graphic capabilities, designed to support teaching of computer science in schools.

Note 2. A 'training day' was the measure of engagement that the DfE specified in Vital's Key Performance Indicators (KPIs) and equated to 5 hours of professional development. 